\title{
Acute retinal necrosis with central retinal artery obstruction
}

\author{
Prabhjot Kaur, ${ }^{1}$ Hrishikesh Kaza, ${ }^{2}$ Avinash Pathengay ${ }^{1}$
}

${ }^{1}$ Retina and Vitreous Service, L V Prasad Eye Institute, GMRV Campus, Visakhapatnam, India ${ }^{2}$ Uveitis Service, LV Prasad Eye Institute, KAR Campus, Banjara Hills, Hyderabad, India

\section{Correspondence to Dr Hrishikesh Kaza; hrishikesh.kaza@gmail.com}

Accepted 30 November 2020

\section{DESCRIPTION}

A 58-year-old man with diabetes, hypertension and immunocompetence presented with diminution of vision in the right eye (RE) for 1 week. His bestcorrected vision in the RE was hand movements. $\mathrm{RE}$ anterior chamber examination revealed three positive cells with keratic precipitates. Significant vitritis with asteroid hyalosis and circumferential large retinitis lesions (figure $1 \mathrm{~A}-\mathrm{C}$ ) were noted on fundus examination. There was a cherry-red spot seen hazily at the macula suggestive of an acute central retinal artery obstruction (CRAO). His left eye examination was unremarkable. Optical coherence tomography of the RE passing through the fovea showed the presence of hyperreflective inner layers suggestive of CRAO (figure 1D). A clinical diagnosis of RE acute retinal necrosis (ARN) with CRAO was made and the patient was started on oral valacyclovir (1 g three times per day) with topical steroids. Intravitreal ganciclovir injection with anterior chamber paracentesis under topical anaesthesia was advised due to the extensive retinal involvement and coexisting CRAO. Systemic investigations revealed non-reactive HIV with controlled blood sugars, normal complete blood counts, erythrocyte sedimentation rate and renal function tests.

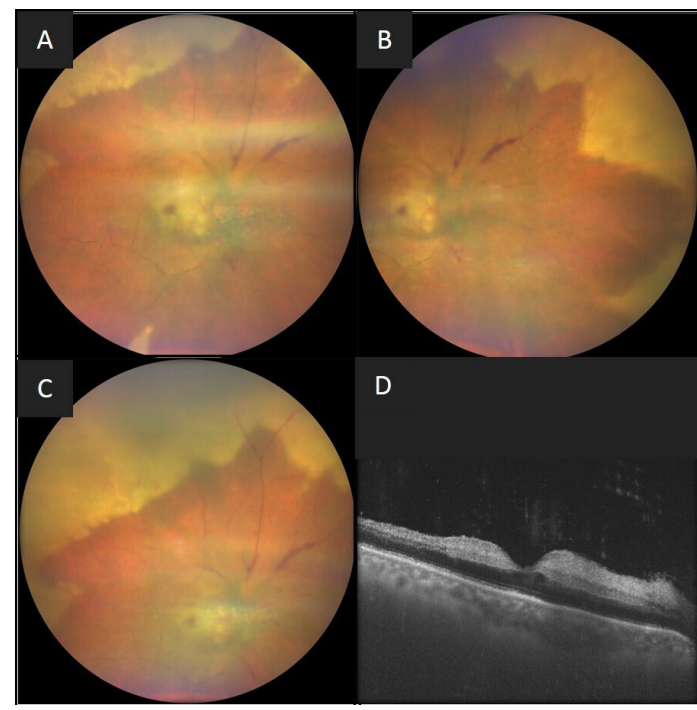

Figure $1 \quad(A-C)$ Fundus photographs of the right eye showing media haze due to vitritis along with the presence of peripheral retinitis patches and a cherry-red spot at the macula; (D) Optical coherence tomography passing through the fovea of the right eye shows the presence of hyperreflective inner layers suggestive of acute central retinal artery obstruction.

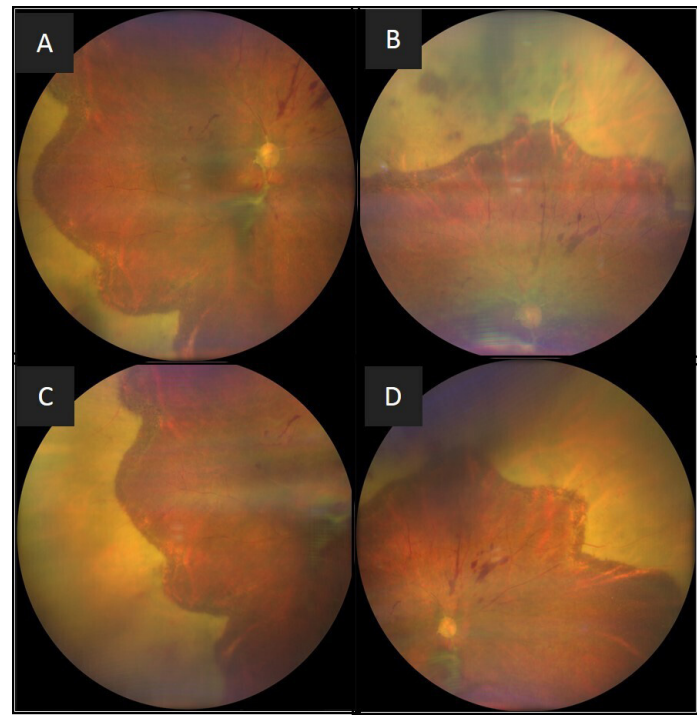

Figure 2 (A-D) Fundus photographs of the right eye of the patient at a 3-week follow-up on oral valacyclovir and post two intravitreal ganciclovir injections showing resolution of retinitis lesion seen along with areas of central clearing in the superior quadrant.

Within a week of starting therapy with oral valacyclovir and having received two intravitreal ganciclovir injections, there was a reduction in the anterior segment inflammation, vitritis and gradual resolution of retinitis. At 3 weeks, there was further improvement (figure 2A-D) noted along with areas of central clearing in the superior quadrant (figure 2B). Simultaneous gradual resolution of cherry-red spot and retinal whitening were noted.

ARN has been associated with central retinal vein occlusion, optic neuropathy, CRAO and CRAO with cilioretinal artery sparing. ${ }^{1-3}$ Systemic association of HSV meningitis has also been described in association with bilateral ARN with CRAO. It may be prudent to note that these occlusions may develop either prior to the occurrence of retinitis lesions of ARN or simultaneously. ${ }^{3}{ }^{4}$ Although extensive vasculitis in patients with ARN has been described, the exact mechanism of the occurrence of occlusive vasculopathy with ARN is unclear. ${ }^{5}$ However, various authors have proposed the possibilities of direct spread of the virus from adjacent retinitis lesions, spread via sensory nerves or an immunemediated response leading to deposition of inflammatory debris within the vascular wall. ${ }^{67}$ Another risk factor for the occurrence of vascular occlusions with ARN is pre-existing vasculopathy secondary to systemic comorbidities. ${ }^{4}$ To conclude, in eyes with ARN, increased awareness of the involvement of 
retinal vessels, including central retinal vessels, is warranted. The involvement of central retinal vasculature in ARN may lead to poor visual outcomes.

\section{Learning points}

- Central retinal vascular occlusions, arterial or venous, are rare associations of acute retinal necrosis.

- Prompt treatment with systemic valacyclovir and intravitreal ganciclovir may be warranted in these situations.

- Despite immediate treatment, the visual prognosis remains poor in these cases.

Contributors PK was involved in collection of data, analysis, writing of manuscript and critical review. HK was involved in manuscript review, critical revision and analysis of available literature for formulating the hypothesis. AP was involved in manuscript review, critical revision and analysis.

Funding The authors have not declared a specific grant for this research from any funding agency in the public, commercial or not-for-profit sectors.
Competing interests None declared.

Patient consent for publication Obtained.

Provenance and peer review Not commissioned; externally peer reviewed.

\section{REFERENCES}

1 Kang SW, Kim SK. Optic neuropathy and central retinal vascular obstruction as initial manifestations of acute retinal necrosis. Jpn J Ophthalmol 2001;45:425-8.

2 Shah SP, Hadid $\mathrm{OH}$, Graham EM, et al. Acute retinal necrosis presenting as central retinal artery occlusion with cilioretinal sparing. Eur J Ophthalmol 2005;15:287-8.

3 Weissman HM, Biousse V, Schechter MC, et al. Bilateral central retinal artery occlusion associated with herpes simplex virus-associated acute retinal necrosis and meningitis: case report and literature review. Ophthalmic Surg Lasers Imaging Retina 2015;46:279-83.

4 Yeh S, Fahle G, Flaxel CJ, et al. Central retinal vascular occlusion associated with acute retinal necrosis. Arch Ophthalmol 2012;130:514-7.

5 Hayreh SS. So-called 'acute retinal necrosis syndrome'--an acute ocular panvasculitis syndrome. Dev Ophthalmol 1985;10:40-773979644.

6 Francés-Muñoz E, Gallego-Pinazo R, López-Lizcano R, et al. Kyrieleis' vasculitis in acute retinal necrosis. Clin Ophthalmol 2010;4:837-820689738.

7 Culbertson WW, Blumenkranz MS, Haines $\mathrm{H}$, et al. The acute retinal necrosis syndrome. Part 2: histopathology and etiology. Ophthalmology 1982;89:1317-25.

Copyright 2020 BMJ Publishing Group. All rights reserved. For permission to reuse any of this content visit

https://www.bmj.com/company/products-services/rights-and-licensing/permissions/

BMJ Case Report Fellows may re-use this article for personal use and teaching without any further permission.

Become a Fellow of BMJ Case Reports today and you can:

- Submit as many cases as you like

- Enjoy fast sympathetic peer review and rapid publication of accepted articles

- Access all the published articles

- Re-use any of the published material for personal use and teaching without further permission

Customer Service

If you have any further queries about your subscription, please contact our customer services team on +44 (0) 2071111105 or via email at support@bmj.com.

Visit casereports.bmj.com for more articles like this and to become a Fellow 